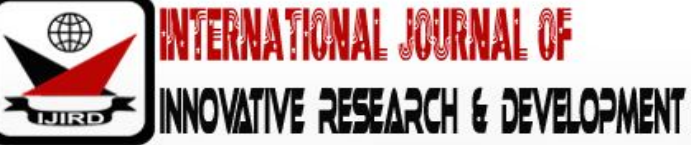

ISSN 2278 - 0211 (Online)

\section{The Impact of Micro Credit on Poverty Alleviation among Women Entrepreneurs in Ile - Ife, Nigeria}

\author{
Popoola Michael Akin \\ Senior Lecturer, Department of History and International Studies, \\ Babcock University, Ilisha-Remo, Ogun State, Nigeria \\ Omosebi Fredrick Adeola \\ Postgraduate Student, Department of Business Administration and Marketing, \\ Babcock University, Ilishan-Remo, Ogun State, Nigeria
}

\begin{abstract}
:
The main objective of the sustainable Development Goals is to transform our world for the better. Central to this transformation is the issue of poverty eradication which is sine qua non to the achievement of other SDGs. Poverty is unarguably, a hydra-headed disease which is ravaging the world like a plague. However its prevalence in the developing countries, including Nigeria, is at intolerable level. A UNESCO Report on poverty index in Nigeria reveals that about 90 per cent of the country's population survive on less than two dollars per day, which means the majority of the country's population are wallowing in abject poverty. Among the corrosive effects of poverty in Nigeria are poor living standard, prevalence of preventable diseases, high mortality rate, and high crime rate among others. At the lowest rung of poverty ladder in the country are the women. Although, women are generally considered to be better in thrift and credit utilization in the informal sector, yet they are poorer than men, due to certain socio-economic barriers which, in most cases, exclude them from access to capital either to invest in or expand some economic activities. However, both the governmental and nongovernmental agencies have increasingly been showing interest in micro-credit as an alternative means of alleviating poverty among the downtrodden. Hence, this study set out to examine the impact of micro credit on poverty reduction, using some women entrepreneurs at Ile-Ife as case study. The study discovered that, all things being equal, micro credit could be an effective strategy for poverty alleviation. The study observed some hindrances which may inhibit the achievement of this goal and made some recommendations in that regard. The study adopted a mixture of quantitative and qualitative method of data collection
\end{abstract}

Keywords: Micro credit, poverty alleviation, women entrepreneurs, sustainable development goal

\section{Introduction}

On 25 September 2015, the United Nations General Assembly adopted a Resolution which contains some social and economic development issues that would serve as post 2015 development agenda for member countries. The Resolution included some broad goals and target which has been variously described as the "Sustainable Development Goals (SDGs)", "the Global Agenda" or "Transforming our world: the 2030 Agenda for Sustainable Development which has been shortened to "Agenda 2030". First on the list of the 17 goals which constitute the Sustainable Development Goals is the Eradication of Poverty.

Poverty is a hydra-headed disease which unarguably commands a serious attention in both the developed and the developing nations. Poverty means more than the lack of income or resources. Rather, it is a general condition of deprivation whose dimensions include social inferiority, isolation, physical weakness, vulnerability, powerlessness and humiliation. In other words, people live in poverty if they lack basic services such as healthcare, security, and education or they experience hunger, social discrimination, and exclusion from decision-making processes. Poverty can demean a human being or make him to feel less human. Little wonder the eradication of poverty is made the first in the list of the SDGs. Where poverty is prevalent, the achievement of other SDGs such as Zero Hunger, Good Health, Quality Education, Gender Equality, Clean Water and many others may be a mere day dream.

The issue of poverty is a global phenomenon. However, its prevalent in the developing countries, including Nigeria is at intolerable level. As a matter of fact, poverty comes first among the indicators of underdevelopment. The enormous resources, both human and natural, which Nigeria is endowed with are either not fully taped or in most cases, grossly mismanaged. This imposed extreme poverty on Nigeria and Nigerians. A recently released report on global poverty index shows that Nigeria has the greatest number of people affected by poverty in the world. The corrosive effects of poverty in Nigeria include; low saving, low investment, poor living standard, prevalence of preventable diseases, high mortality rate, threatened peace and security and high crime rate among others. 
Suffice it to say also that poverty has gender dimension in Nigeria. The socio-economic and cultural discrimination against women in the country put them at the lowest rung of poverty ladder. Although, women are generally considered to be better in thrift and credit utilization in the informal sector, yet they are poorer than men because certain hindrances such as lack of collateral and unemployment exclude them from access to capital either to invest in, or expand some economic activities.

Micro-credit is recognized world-wide as a powerful economic development enabler and an important tool in alleviating poverty (Bayes, 2005). Micro-credit schemes enables the poor to increase their household income, build assets and reduce their vulnerability to daily life crises. It also bolsters investment in children's education; improve nutrition and utilization of appropriate healthcare services as well as planning for the future. These are part of the issues which the SDGs are targeting. The objective of this research therefore, is to examine whether micro finance can serve as a tool for poverty alleviation among Nigerian women, using some women entrepreneurs at Ile Ife as a case study.

\section{Literature Review}

Evidence from the literature supports the supposition that women are part of the missing links in the development quagmire confronting the least developed economies such as Nigeria. The fact that women account for the production of over half of the food produced through manual labor in developing countries, in addition to the household chores of cooking, fetching of water and fuel wood, caring for children and keeping the house tidy, make them a vital part of the economy (Anyanwu, 1994) and (Manimekalai, 2004).Despite this, they are largely disenfranchised from the empowerment conferred by the formal financial system, largely, as a result of the undue disadvantages foisted upon them by the existing socio-cultural institutions in Nigeria. Hence, the position of perpetual poverty which this consign them to calls for an urgent and sustainable poverty alleviation strategy.

Kakwani and Pernia (2000) state that Poverty alleviation is all about improving human wellbeing in general and that of the poor people in particular. To Shil (2009), poverty alleviation is the act of reducing the scourge of poverty of an individual or community. According to Alao, Ojo and Popoola (2013), the successive governments in Nigeria have initiated several poverty alleviation programmes which did not achieve much success. Hence, the government of the country has appreciated the importance of micro-lending as a potent means of alleviating poverty especially among the rural people which constitute about 70\% of Nigeria population. Taking this further, Ogundele et al (2012) points to the fact that the government of Nigeria has acknowledge the importance of mainstreaming women into the national development process by introducing formal microcredit policy and making it favourable to them.

It is generally believed that micro-lending can facilitate the development of small businesses and enhanced the emergence and consolidation of new entrants into businesses (Nkpoyen et al, 2012).In a developing country like Nigeria where the majority of thepopulation are women, living in rural areas, any genuine intention aimed at poverty alleviation must involve the availability of micro-lending to the women who have always been the disadvantaged specie.

Koontz \& Weihrich, 2006, are of the view that acquisition of microfinance could lead to opportunity for entrepreneurial activity, especially among the women. Salman, (2009), added his voice to this by emphasizing that the appropriate use of acquired micro-credit resources through good business strategy and organizational design could lead to good business performance

Makombe et al (2001), and Olabode\& Ebegbede (2009), opine that micro-lending programmes have been greatly utilized, especially by the disadvantaged groups and communities, as source of economic power. This has also created business consciousness among women and helped to revive the rural economy by creating avenues for self-employment. This is in tandem with the view of Schwettmann, (1997) who opines that micro-lending encourages the development of business consciousness among women.

In the same vein, Vosantakumari \& Sharma, (2010) assert that the emergence of micro-lending is a veritable alternative to the conventional banking and it has been recognized globally as a means of empowering the downtrodden so as to lift them up from the clutches of poverty.

The above reviewed literature have romanticized the correlation between poverty alleviation and micro-credit. They have evinced the idea that the activities of women entrepreneurs will have a positive social as well as economic effects for the women themselves and their socio-economic environment if only they are given access to micro-credit. The literature however failed to take cognizance of some factors such as religious belief, conducive business environment, 'conditionalities' of the micro-credit given and the family size which may demean the effect of micro-credit.

\section{Methodology}

The study is concerned with examining the impact of micro credit on poverty reduction among women entrepreneur in Ile-Ife, Osun State, Nigeria. The study encompasses women who have taken advantage of the Lift Above Poverty Organization (LAPO)micro-credit scheme.

\subsection{Design}

The study adopted exploratory/ descriptive survey research design in investigating the impact which micro-credit could have on poverty alleviation.

\subsection{Participants}

300 Respondents from various communities were randomly selected from the three local government areas in Ile - Ife (Ife Central, Ife East and Ife North Local Government Areas) Osun State. The stratified random sampling technique 
was used to select the respondents from each of the Local Government Areas so as to give the chances of being chosen by each member of the population. The targeted age is between twenty (20) and Fifty (50) years.

\subsection{Instruments}

The research instrument for the study is a structured questionnaire drawn primarily to collect information on the impact of micro credit and poverty reduction among women entrepreneurs. Copies of the questioner were filled by women who are responsible for the day to day running of their businesses.

\subsection{Procedure}

The researchers, with the assistance of two other people administered the questionnaire. Data collection lasted one week. Completed inventories were thoroughly checked to ensure that they were properly filled. The Statistical Package for Social Sciences (SPSS) 20.0 was used in the analysis of data collected. The researchers deemed this package most appropriate in this research given its veracity and considering the nature of data collected

\subsection{Response Rate}

Three hundred copies of questionnaire were distributed to the women, out of which287 were returned and collated. This gives a response rate of $96 \%$.

\section{Analysis of Data}

This section examines the responses from the women entrepreneurs on how micro-credit loan has assisted in the reduction of poverty among the women entrepreneur. The tables were grouped based on the questions and the responses given to the questions raised.

\begin{tabular}{|c|c|c|c|c|c|c|}
\hline S/ N & Questions & Very Low & Low & Undecided & High & Very High \\
\hline 1 & $\begin{array}{c}\text { To what extent would you say that } \\
\text { Poverty is Prevalent in Nigeria }\end{array}$ & - & $30.0 \%$ & $4.9 \%$ & $50.5 \%$ & $14.6 \%$ \\
\hline 2 & $\begin{array}{c}\text { What is your Scope of Knowledge } \\
\text { about other Micro credit loan }\end{array}$ & $29.3 \%$ & $50.9 \%$ & - & $19.9 \%$ & - \\
\hline 3 & $\begin{array}{c}\text { What impact has Micro credit made } \\
\text { on your business }\end{array}$ & $9.8 \%$ & $25.4 \%$ & - & $50.2 \%$ & $14.6 \%$ \\
\hline 4 & $\begin{array}{c}\text { What is the level of Convenience } \\
\text { in the method of repayment to you }\end{array}$ & - & $30.0 \%$ & - & $50.5 \%$ & $19.5 \%$ \\
\hline 5 & $\begin{array}{c}\text { To what extent has the availability of } \\
\text { Micro credit improve the status of } \\
\text { women in your community }\end{array}$ & $14.6 \%$ & $14.6 \%$ & - & $20.2 \%$ & $50.5 \%$ \\
\hline
\end{tabular}

Table 1: Response to Questions on Poverty and Micro-Credit

Table 1, show that the women entrepreneurs responded to questions relating to the issue on Poverty and Microcredit and this gave an insight to the importance of micro-credit in reduction of poverty. The response to question 1 revealed that $50.5 \%$ of the women entrepreneur disclosed that poverty prevalent in Nigeria is on the high side and this prompted them to seek alternative solution in reducing poverty through accessing the micro credit loan.

The scope of knowledge of the women entrepreneurs about other micro-credit facilities available in the country (ADRA credit interventions) showed that 50.9\% of them have low knowledge about other micro-credit facilities. This can be attributed to lack of awareness and right marketing strategy on the part of the loan providers. On the impact microcredit has made on the women entrepreneurs business, the response rate of $50.2 \%$ revealed that micro-credit loan has gone a long way to improve the business of the women through improvement in the stock level thereby generating increase in profit.

More so, in examining the level of convenience in the method of repayment $50.5 \%$ of the women shows that the level of repayment is convenient for them as they find it easy to repay the loan according to the repayment guidelines set by the micro credit institution. Despite this, 30.0\% still finds it inconvenient to repay the loan among the women entrepreneur. The women in this category find the condition for repayment to be stringent. While answering the question on the extent to which micro credit has improved the status of women in the community, $50.5 \%$ of the beneficiaries revealed that the improvement on the status of the women is very high as most of the women have access to more capital through micro-credit to improve the level of their business thereby transforming business on the verge of collapse to a flourishing business.

From Table 1 above, it can be deduced that despite the assistance given to women through micro credit loan, most women entrepreneurs still find it difficult to access additional loan from other micro finance institutions, majorly due to lack of knowledge of the other loan facility. Also the women were able to establish that women who have been able to access the loan have experienced a new turn around in their businesses. This has assisted in the reduction of poverty which is one of the Sustainable Development Goals. 


\begin{tabular}{|c|c|c|c|}
\hline S/ N & Variable & Frequency & Percentage \\
\hline 1 & Very easy & 72 & 25.1 \\
\hline 2 & Easy & 58 & 20.2 \\
\hline 3 & Difficult & 43 & 15.0 \\
\hline 4 & Very Difficult & 114 & 39.7 \\
\hline & & 287 & 100 \\
\hline
\end{tabular}

Table 2: Response to Question on the Process of Obtaining the Loan

Table 2 revealed that $39.7 \%$ of the women entrepreneurs finds it very difficult to have access to micro credit as the process of obtaining the loan has a lot of stringent rules and regulation. On the other hand $25.1 \%$ of them finds it very easy while $20.2 \%$ finds it easy.

\begin{tabular}{|c|c|c|c|}
\hline S/ N & Questions & Yes & No \\
\hline 1 & $\begin{array}{c}\text { Have you ever accessed any Micro- } \\
\text { credit loan (before ADRA loan) }\end{array}$ & $70 \%$ & $30 \%$ \\
\hline 2 & $\begin{array}{c}\text { Has micro credit loan reduced poverty } \\
\text { in your family }\end{array}$ & $69.7 \%$ & $30.3 \%$ \\
\hline 3 & Do you repay loan on regular basis & $70 \%$ & $30 \%$ \\
\hline 4 & $\begin{array}{c}\text { How would you describe the loan being } \\
\text { given by micro credit institutions? Is it } \\
\text { substantial enough? }\end{array}$ & $49.5 \%$ & $50.5 \%$ \\
\hline 5 & $\begin{array}{c}\text { Would you recommend micro credit to } \\
\text { other women who are facing the } \\
\text { challenge of poverty }\end{array}$ & $65.5 \%$ & $34.5 \%$ \\
\hline
\end{tabular}

Table 3: Response to Questions on Access to Micro-Credit Loan

From Table 3 the women entrepreneurs provided insight into issues on the relationship between poverty and micro credit loan. The result from Table 3 shows that $70 \%$ of the women entrepreneurs have been accessing micro credit loan for the growth of their business while $30 \%$ of the women revealed that they were first timers in accessing micro credit loan. By implication, majority of the women have been accessing the loan for the growth of their business before ADRA offered them credit facilities

On the effect of micro credit loan and poverty reduction, $69.7 \%$ of the women agreed that micro credit loan has assisted in the reduction of poverty among the women as most of the women who, otherwise would have been unemployed housewives became owners of businesses, thereby rendering assistance to their husbands in therunning of their homes.

Table 3 reveals that $70 \%$ of the women responded positively to regular repayment of loan collected. This gives most of the women the opportunity of getting access to higher amount of loan than what they have accessed before.On the issue of whether the loan given is substantial enough, Table 3 also reveals that $49.5 \%$ of the women agreed that the loan is substantial while 51.5\% established that it is not substantial enough. By implication, the loan given by the micro credit lenderstill needs to be further enhanced or increased as the women desire to have more loans for the expansion of their various businesses. Moreover, Table 3 revealed that $65.5 \%$ of the women would love to recommend micro credit facility to other women while $34.5 \%$ decline. This implies that majority of the entrepreneurs are benefitting greatly from the yield of the micro credit loan which can prompt them to recommend it to other women who are either struggling with poverty or has little or no income in establishing a business.

\begin{tabular}{|c|c|c|c|c|c|c|}
\hline S/ N & Questions & $\begin{array}{c}\text { Strongly } \\
\text { Disagree }\end{array}$ & Disagree & Undecided & Agree & $\begin{array}{c}\text { Strongly } \\
\text { Agreed }\end{array}$ \\
\hline 6 & $\begin{array}{c}\text { The collateral demanded by micro credit } \\
\text { institutions are too stringent }\end{array}$ & $9.8 \%$ & $15.06 \%$ & - & $55.1 \%$ & $20.2 \%$ \\
\hline 7 & $\begin{array}{c}\text { Do you agree that pre-lending training is } \\
\text { necessary for a successful loan usage }\end{array}$ & - & $15.3 \%$ & - & $45.6 \%$ & $39.0 \%$ \\
\hline 8 & $\begin{array}{c}\text { It is possible to obtain start-up funding from } \\
\text { micro credit institutions by low income } \\
\text { groups }\end{array}$ & $20.2 \%$ & $64.8 \%$ & - & $15.0 \%$ & - \\
\hline 9 & $\begin{array}{c}\text { It is very important that more micro credit } \\
\text { institutions should be established in the rural } \\
\text { areas }\end{array}$ & - & $34.5 \%$ & - & $50.5 \%$ & $15.0 \%$ \\
\hline 10 & $\begin{array}{c}\text { The size of your family makes loan } \\
\text { repayment difficult }\end{array}$ & - & $30.0 \%$ & - & $70.0 \%$ & - \\
\hline 11 & $\begin{array}{c}\text { Loan repayment has really affected the } \\
\text { growth of your business }\end{array}$ & $10.5 \%$ & $34.5 \%$ & - & $39.7 \%$ & $15.3 \%$ \\
\hline 12 & $\begin{array}{c}\text { You need to embark on other types of } \\
\text { contribution to grow your business }\end{array}$ & - & $20.2 \%$ & - & $65.2 \%$ & $14.6 \%$ \\
\hline
\end{tabular}




\begin{tabular}{|c|c|c|c|c|c|c|}
\hline S/ N & Questions & $\begin{array}{c}\text { Strongly } \\
\text { Disagree }\end{array}$ & Disagree & Undecided & Agree & $\begin{array}{c}\text { Strongly } \\
\text { Agreed }\end{array}$ \\
\hline 13 & $\begin{array}{c}\text { It has been generally assumed that micro- } \\
\text { credit serves as a sure panacea to poverty }\end{array}$ & $9.8 \%$ & $9.8 \%$ & - & $30.3 \%$ & $50.2 \%$ \\
\hline 14 & $\begin{array}{c}\text { There are wide differences between micro } \\
\text { credit and other traditional micro credit }\end{array}$ & $4.9 \%$ & $14.6 \%$ & - & $30.7 \%$ & $49.8 \%$ \\
\hline 15 & $\begin{array}{c}\text { It has been said that some people divert the } \\
\text { money they were given by micro finance } \\
\text { institutions }\end{array}$ & - & $69.7 \%$ & - & $30.3 \%$ & - \\
\hline 16 & $\begin{array}{c}\text { The money given by micro credit institutions } \\
\text { is enough to reduce poverty }\end{array}$ & - & $30.3 \%$ & - & $34.8 \%$ & $34.8 \%$ \\
\hline
\end{tabular}

Table 4: Response to Questions on Micro-Credit Facilities

From Table 4 it is established by $55.1 \%$ of the women entrepreneurs that the collateral demanded by micro-credit institutions are too stringent and this often times hinders most women entrepreneur from accessing the micro credit loan. By implication stringent rules and regulation before accessing loan often times discourage investment and usage of productive ideas which are factors that can contribute to reduction of poverty in any economy.

Pre lending training has been identified as part of the activities micro credit institution does before disbursement of loan to their customers. From Table 4, 45.6\% agreed while 39\% strongly agreed that pre-lending training is necessary for successful loan usage. Furthermore, from preliminary investigations, the women entrepreneurs have established that prelending training serve as eye-opener to the women on how they can effectively make use of the loan so as to make repayment easy. More so, it has given them opportunity of diversification of business so as to make use of the loan granted in divers' ways.

Another issue identified from Table 4 is the possibility of obtaining start-up funding from micro credit institutions by low income women entrepreneurs. $64.8 \%$ of the women disagreed that the micro credit institution gives loan for startup. This has been having adverse effects on some women who wish they could have startup capital to start a new business idea and vision. Startup capital is not the main target of the micro credit institutions in reduction of poverty but to improve on existing business

From preliminary investigations, it was deduced that poverty is more prevalent among women in the rural areas than women in the city. This assertion was corroborated in Table 4 as $50.5 \%$ of women supported the establishment of micro-credit institutions in the rural areas than in the city.

Moreover, Table 4 above showed that $70 \%$ of the women established that the size of their family make repayment of loan difficult, as provision of family needs encroached into the usage of the loan facilities advanced to them for business purposes. By implication, family size can be identified as a factor hindering reduction in poverty in the economy.

The response to the issue of loan repayment revealed that 34.5\%of the respondents did not agree that loan repayment has affected the growth of their business while $39.7 \%$ agreed that loan repayment has some negative impact on their business. Also 15.3\% strongly agree that loan repayment do affect the growth of their business. This implies that majority of the women are not finding it easy in repaying the loan. This can be attributed to the stringent rules attached to the repayment of the loan.

Due to the stringent rules placed on loan repayment, $65.2 \%$ of the women entrepreneurs agreed that they had to embark on other types of contribution to grow their business. By implication the women entrepreneurs established that they patronize patronized other credit granting group or body so as to augment repayment of loan and meet extra demand of money by their businesses.

As a means of reduction in poverty, $50.2 \%$ of the women strongly agreed while $30.3 \%$ agreed that micro credit serves as a sure panacea to poverty reduction. Most of the women from preliminary investigation have stated that their financial status have improved and from the response gathered, $85 \%$ of the women established that micro credit loan have assisted in reduction of their poverty level

Similarly, $30.7 \%$ of them agreed while $49.8 \%$ strongly agreed that there is a wide difference between micro credit and other traditional credit institutions such as Ajo, Esusu etc. They also agreed that the traditional credit scheme is not as beneficial to business expansion as the micro credit scheme. Hence, the women supported the continued existence of micro credit institutions which can give them short term loan for the expansion of their businesses with no collateral or savings.

The study addressed the issue of diversion of loan given, with $69.7 \%$ of the women entrepreneurs disagree that the loan given by micro credit institution cannot be diverted to be used for other things. Though $30.3 \%$ of the women still established that there is diversion but majority of the women revealed that diversion of the loan is at the minimum level.

In response to the question whether the money given by micro credit institutions is enough to alleviate poverty,34.8\% of the women agreed and $34.5 \%$ strongly agreed that micro credit assistance can go a long way to alleviate poverty. By implication, micro credit institutions have been assisting the government in the achievement of sustainable development goals of poverty reduction.

\section{Discussion}

The women entrepreneurs have been able to shed light on the effectiveness of micro credit as a strategy for poverty reduction. About $64.8 \%$ of the women entrepreneurs established the fact that micro credit loan has made significant impact on their businesses. This implies that the women were much more aware that micro credit loan is one of the most 
important strategy that can be put in place to reduce poverty. This was confirmed in question 9 , where $69.7 \%$ of the women established the fact that micro credit loan have contributed to reduction of poverty in their various families

Furthermore, $65.5 \%$ of the women agreed to recommend micro credit loan to other women who are facing the challenge of poverty and whose businesses were on the verge of collapse. To further buttress our findings, $50 \%$ of the women agreed that the loan given was substantial enough while $50 \%$ also disagreed that the loan given was not substantial enough. This implies that there is the need for the micro finance institution to increase the amount of money they give to women entrepreneurs so as to aid the expansion of their various businesses.

\subsection{The Challenges of Accessing Micro-Credit Facility in Nigeria}

Some challenges have been associated with obtaining micro-credit facility in Nigeria. One of the challenges is exemplified in question 5 under table 1.2 in which $54.7 \%$ of the women established that it is very difficult to access and process the loan as there are lots of stringent rules and regulations to be followed. Another challenge identified is the mode of repayment of the loan. As shown by Table 4, question 14,54\% of the women revealed that the mode of loan repayment has affected the growth of their business negatively. Furthermore, Table 4 question 16 revealed that $79.8 \%$ of the women agreed on the need to embark on other types of contribution to grow their businesses as often times, micro credit loan is not enough to take care of their business expansion plan

In Table 4 question 21 revealed that the credit facilities given to some of the women entrepreneurs are sometimes diverted for another purposes. This undoubtedly deplete the cash liquidity in the possession of micro-credit institutions and as well have a negative effect on the ability of the institutions to disburse more money to those who need greater amount or new customers that need fresh loan.

\section{Conclusion}

In conclusion, the result of this research has established the fact that micro credit loan is a panacea to poverty reduction among women entrepreneurs in Nigeria. The result revealed that micro credit has impacted their businesses positively and this has led to a significant improvement in the status of the women entrepreneur beneficiaries so much so that the women are willing to recommend micro credit to other women who are facing the challenge of poverty. While a reasonable percentage of the women beneficiaries of the loan believed that the money being given by micro credit institutions is enough to reduce poverty, some of the women opine that they would have preferred an increase in the amount of loan so that it can make a significant impact on their businesses and by extension, on poverty reduction. Finally, this research concludes by saying that if the government of Nigeria is sincere about achieving the first Sustainable Development Goal, it should put in place policies that would promote the accessibility of the downtrodden people to micro-credit.

\section{Recommendations}

Given the important role which micro-finance institutions play in poverty alleviation, this research recommends that the institutions need to consider an upward review of the loan they advance to women entrepreneur. Given the peculiar condition/ experience of some women, the loan given may not make any notable changes in their lives if the money is not substantial enough.

Furthermore, micro finance institutions are urged to look into the policy that guides loan repayment in order to make it more borrower friendly.

Women are advised to form or join cooperative societies so that they can have more bargaining strength as regards the amount of loan available to them and the mode of repayment as well.

Women are also advised to imbibe birth control/ family planning devise so that they would have sizeable family that they would be able to manage. It is then that their efforts to get out of the woods of poverty can be effective.

\section{References}

i. Anyanwu, J.C. (1994). Women's education and the use of bank credit in Nigeria: challenges for the twenty first century, Journal of Social Development in Africa, 9 (2),45-59.

ii. Bayes, A. (2005). Micro-credit and women's empowerment. USA: World Prout Assembly.

iii. Kakwani, N. \& Pernia, C. (2000). What is pro-poor growth. Asian Development Review, 8(1), 1-16.

iv. Koontz, H. \& Weihrich, H. (2006). Essentials of Management. Tata McGraw Hill.

v. Makombe, A.M., Temba, E. \& Kihomb, A.R. (2001). Credit schemes and women empowerment for poverty alleviation: The case of Tanga Region, Tanzania. Research Report No. 99/ 1/ 19-30.

vi. Manimekakai, N. (2004). Impact of various forms of micro financing on women. Paper Submitted to Department of Women and Child Development, Ministry of Human

vii. Resources Development, Government of India.

viii. Nkpoyen, F \& Bassey, G.E. (2012). Micro-lending as an empowerment strategy for poverty

ix. alleviation among women in Yala Local Government Area of Cross River State, Nigeria. International Journal of Business and Social Science, 32(18), 233-241.

x. Ogundele, J.J.K., Akingbade, W.A \& Akinlabi, H.B. (2012). Entrepreneurship training and education as strategic tools for poverty alleviation in Nigeria. American International Journal of Contemporary Research, 2(1), 148-156.

xi. Olabode, B.O. \& Elegbade, O. (2009). Poverty in rural areas of Nigeria: A brief review of causes, consequences and alleviation method. Journal of Social and Policy 
xii. Salman, A. (2009). How to start a business: A guide for women. Pakistan Center for International Private Enterprise Institute of National Private Enterprise Institute of National Endowment for Democracy, affiliate of the USA Chamber of Commerce.

xiii. Schiller, B. R. (1997). Poverty and discrimination. New York: Russell

xiv. . Schwettmann, J. (1997). Cooperatives and employment in Africa.Geneva: International Labour Organization.

xv. Shil, N.C. (2009). Microfinance for poverty alleviation: A commercialized view. International Journal of Economics and Finance, 1(2), 191-205.

xvi. Vosathakumari, R.M. \& Sharma, V.J. (2010). Microcredit: The theoretical framework and empirical evidence.New Delhi: Vistaar Publications. 